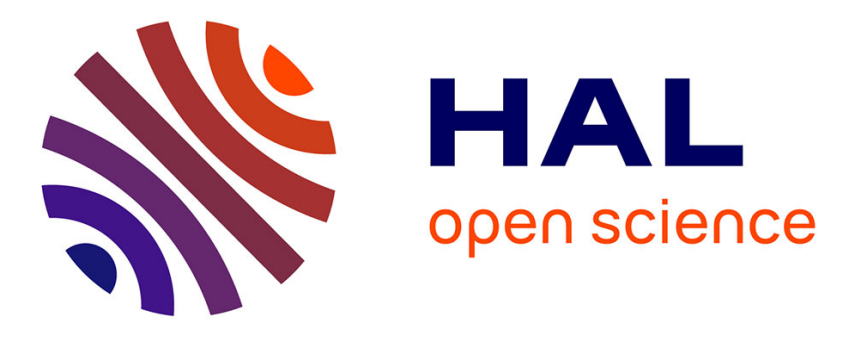

\title{
Confining caesium in expanded natural Perlite
}

Jean Luc Rehspringer, J. Balencie, Serge Vilminot, Didier Burger, Anne Boos, Claude Estournès

\section{To cite this version:}

Jean Luc Rehspringer, J. Balencie, Serge Vilminot, Didier Burger, Anne Boos, et al.. Confining caesium in expanded natural Perlite. Journal of the European Ceramic Society, 2007, vol. 27 (2-3), pp. 619-622. 10.1016/j.jeurceramsoc.2006.04.118 . hal-00808243

\section{HAL Id: hal-00808243 \\ https://hal.science/hal-00808243}

Submitted on 5 Apr 2013

HAL is a multi-disciplinary open access archive for the deposit and dissemination of scientific research documents, whether they are published or not. The documents may come from teaching and research institutions in France or abroad, or from public or private research centers.
L'archive ouverte pluridisciplinaire HAL, est destinée au dépôt et à la diffusion de documents scientifiques de niveau recherche, publiés ou non, émanant des établissements d'enseignement et de recherche français ou étrangers, des laboratoires publics ou privés. 


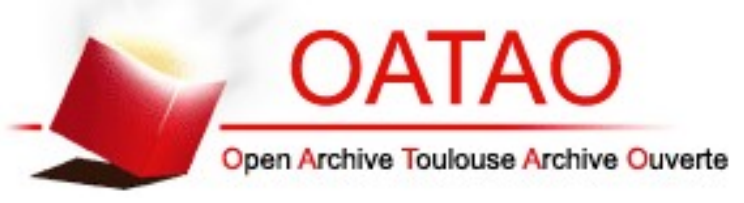

\section{Open Archive Toulouse Archive Ouverte (OATAO)}

OATAO is an open access repository that collects the work of Toulouse researchers and makes it freely available over the web where possible.

This is an author-deposited version published in: http://oatao.univ-toulouse.fr/ Eprints ID : 2472

To link to this article :

URL : http://dx.doi.org/10.1016/j.jeurceramsoc.2006.04.118

To cite this version : Rehspringer, Jean Luc and Balencie, J. and Vilminot, S. and Burger, D. and Boos, A. and Estournès, Claude ( 2007) Confining caesium in expanded natural Perlite. Journal of the European Ceramic Society, vol. 27 ( $\mathrm{n}^{\circ} 2$ - 3). pp. 619-622. ISSN 0955-2219

Any correspondence concerning this service should be sent to the repository administrator:staff-oatao@inp-toulouse.fr 


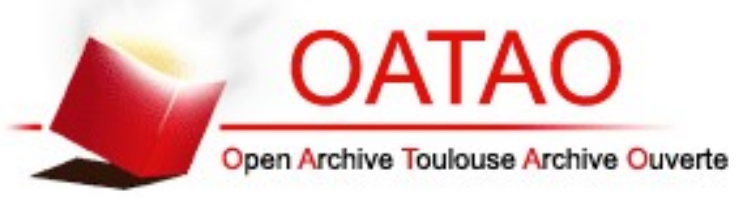

\section{Open Archive Toulouse Archive Ouverte (OATAO)}

OATAO is an open access repository that collects the work of Toulouse researchers and makes it freely available over the web where possible.

This is an author-deposited version published in: http://oatao.univ-toulouse.fr/ Eprints ID : 2472

To link to this article :

URL : http://dx.doi.org/10.1016/j.jeurceramsoc.2006.04.118

To cite this version : Rehspringer, Jean Luc and Balencie, J. and Vilminot, S. and Burger, D. and Boos, A. and Estournès, Claude ( 2007) Confining caesium in expanded natural Perlite. Journal of the European Ceramic Society, vol. 27 ( $\mathrm{n}^{\circ} 2$ - 3). pp. 619-622. ISSN 0955-2219

Any correspondence concerning this service should be sent to the repository administrator:staff-oatao@inp-toulouse.fr 


\title{
Confining caesium in expanded natural Perlite
}

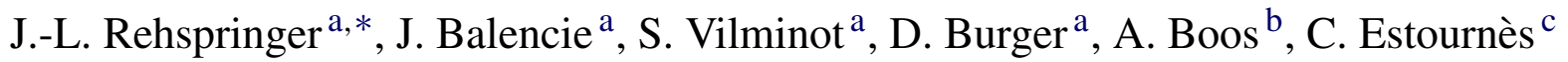 \\ ${ }^{a}$ IPCMS-GMI, UMR CNRS-ULP 7504, 23 rue du Loess, BP 43, Strasbourg 37034, Cedex 2, France \\ ${ }^{\mathrm{b}}$ LCAM, UMR 7512, ECPM, 26 rue Becquerel, Strasbourg 67087, Cedex 2, France \\ ${ }^{\mathrm{c}}$ CIRIMAT UMR 5085 CNRS-UPS, 118 route de Narbonne, Toulouse 31062, France
}

\begin{abstract}
We present the potential use of expanded perlite, a metastable amorphous hydrated aluminum silicate, as a permanent medium for the long-term confinement of caesium. A simple loading by mixing an aqueous caesium nitrate solution and expanded perlite at $300 \mathrm{~K}$ followed by thermal annealing leads to $96 \%$ sintering. The formation of pollucite, $\mathrm{CsAlSi}_{2} \mathrm{O}_{6}$, a naturally occurring mineral phase, appears as the crystalline phase embedded in a glassy phase. Leaching tests on the resulting glass-ceramics reveal a very low Cs departure of $0.5 \mathrm{mg} \mathrm{m}^{-2} \mathrm{day}^{-1}$. This simple method seems to be a good way to permanently confine caesium issued from recycled nuclear waste.
\end{abstract}

Keywords: Sintering; Leaching process; Nuclear applications

\section{Introduction}

The generation of large quantities of environmentally unfriendly nuclear waste, for example those with long-lived radioactivity, sets to humans a great problem for now and the future. Ways of separating and storing these materials are of constant debate and promote the search for efficient methods of finding containers for their safe storage for long-term periods spanning over thousand years. One of the nucleids under debate in the France is radioactive ${ }^{137}$ caesium issued from nuclear fuel recycling process in the La Hage plant. Our interest has been in finding suitable host for the storage of caesium and its decayed products. The present paper reports the use of expanded perlite on a laboratory level for trapping natural caesium.

Borosilicate glass, glass-ceramics, caesium-loaded zeolites and pollucite have been shown to be potential candidates for storage. Pollucite, $\mathrm{CsAlSi}_{2} \mathrm{O}_{6}$, can accommodate up to $40 \mathrm{wt} . \%$ $\mathrm{Cs}$ into its structure thus producing a highly dense waste form. Furthermore, the measured solubility of pollucite is lower while the leakage of Cs from pollucite are three orders of magnitude less than those for silicate glasses. ${ }^{1}$ Therefore, various synthetic methods have been considered for pollucite using self-propagating high-temperature synthesis (SHS), ${ }^{2}$ reaction between gaseous Cs and fly ash, ${ }^{3}$ hydrothermal, ${ }^{4}$ arc melting

\footnotetext{
* Corresponding author. Tel.: +33 3881071 90; fax: +33 388107247.

E-mail address: rehsp@ipcms.u-strasbg.fr (J.-L. Rehspringer).
}

technique, ${ }^{5}$ ion exchange in zeolites ${ }^{6}$ and crystallization from a glass. ${ }^{7}$ Moreover, pollucite is a naturally occurring mineral with a three-dimensional structure that contains and irreversibly traps more Cs. ${ }^{8}$ The resulting samples have been the subject of several characterizations in view of their possible application as waste form such as thermal expansion coefficient measurements, ${ }^{9}$ leaching tests, ${ }^{7}$ sinterability, effect of beta radiation effects ${ }^{10}$ and radiogenic transmutation. ${ }^{11}$ The possibility to obtain pollucite from zeolites ${ }^{8}$ stimulates the research of other aluminosilicate minerals. These results are very encouraging and have driven us to search for other related materials and here, we focus on a metastable amorphous hydrated aluminum silicate, perlite.

Perlite with typical average chemical analysis $71-75 \mathrm{wt} . \%$ $\mathrm{SiO}_{2}, 12.5-18$ wt. $\% \mathrm{Al}_{2} \mathrm{O}_{3}, 4-5$ wt. $\% \mathrm{~K}_{2} \mathrm{O}, 1-4$ wt. $\% \mathrm{Na}_{2} \mathrm{O}$ and $\mathrm{CaO}$, traces of metal oxides and $2-5 \mathrm{wt} . \%$ water $^{12}$ is the naturally occurring mineral issued form rapid cooling of undersea igneous rocks. However, perlite is mainly used in its expanded form which is obtained by flame spreading of powered mineral. It results in an extremely light material looking like glass pearls with a large void in the core. Expanded perlite is fire resistant and acts as an excellent thermal and acoustical insulator. The open structure of expanded perlite can also be exploited for the insertion of waste mineral cations (for example: $\mathrm{Cs}$ ) from aqueous solutions. Due to the strong excess of silicon compared to aluminum, the formation of a glass ceramics is expected with pollucite as the crystalline phase. The localization of Cs in pollucite will potentially decrease its leakage. ${ }^{5}$ Finally, expanded 
perlite is a ready-to-use material with a very reasonable cost. All these considerations stimulate the study of the use of perlite for the confinement of Cs. ${ }^{13}$ Our works were carried out on natural caesium in order to estimate the stability of perlite matrix upon water leaching who can occurs in deep underground deposits.

\section{Experimental}

\subsection{Synthesis}

Expanded perlite was produced by Thermal Ceramics de France who produce flame resistant panel. An aqueous caesium nitrate, $\mathrm{CsNO}_{3}$ (Aldrich, 99\%), solution was dropped in expanded perlite in a 5:1 weight proportion in order fully cover the apparent volume of powder and homogeneously disperse caesium. Different amounts of $\mathrm{CsNO}_{3}$ were dissolved in a constant volume of water in order to achieve various $\mathrm{Cs}_{2} \mathrm{O}$ /perlite weight ratios between 5 and $50 \mathrm{wt} \%$. The resulting samples were then dried at $423 \mathrm{~K}$ to remove water. In order to check the influence of the porosity, similar samples have been elaborated starting from thoroughly ground powders of the expanded perlite. Dense pellets for the leaching tests have been prepared using different techniques: (1) pre-calcination at $1373 \mathrm{~K}$ for $1 \mathrm{~h}$ to reduce the sample volume, grinding, shaping into pellets and sintering at $1293 \mathrm{~K}$ for $1-3 \mathrm{~h}$, (2) starting from ground perlite, followed by direct caesium loading and direct sintering at $1293 \mathrm{~K}$ in a crucible with a small load, and (3) sintering using the flash technique. Samples were sintered at $1123 \mathrm{~K}$ for $5 \mathrm{~min}$ in a Spark Plasma Sintering (SPS) furnace, Dr. Sinter 2080 (Sumitomo Coal Mining). Before sintering, expanded perlite powders were directly loaded into cylindrical graphite die with inner diameter of 8 or $20 \mathrm{~mm}$ and then put into the sintering chamber that was evacuated to $3 \mathrm{~Pa}$. The control of the heating rate was made by a computer program system and the temperature was recorded by a thermocouple fixed on a small hole at the external surface of the graphite die. A pressure of $25 \mathrm{MPa}$ was applied by manual operation and not released until the beginning of cooling stage. A constant heating rate of $100 \mathrm{~K} \mathrm{~min}^{-1}$ was applied during each sintering cycle. Contrary to borosilicate glass used to dissolve caesium and other nuclide (R7T7 COGEMA) we also try to obtain a castable glass. But, moulding from the liquid was not possible due to its high viscosity even at temperatures as high as $1823 \mathrm{~K}$.

\subsection{Characterizations}

Chemical analyses were performed by ICP-MS technique with a Plasma Quad ICP/MS instrument equipped with Meinhard nebulizer. Operating conditions were single ion monitoring at $\mathrm{m} / \mathrm{z}$ 133; plasma gas: $141 \mathrm{~min}^{-1}$, auxiliary gas: $11 \mathrm{~min}^{-1}$, nebulizer gas: $0.751 \mathrm{~min}^{-1}$. Cs solutions used for calibration were daily prepared on a mass basis by non-consecutive dilutions of a CPI stock certified solution ( $1 \mathrm{~g} \mathrm{l}^{-1}$ in Cs) with $2.5 \%$ nitric acid (Suprapur Merck). The leaching solutions were diluted 10 times with $2.5 \%$ nitric acid (Suprapur Merck) before analysis. TGDTA experiments were performed on a TA instrument under air at a $5{ }^{\circ} \mathrm{C} \mathrm{min}^{-1}$ heating rate. The leaching tests have been per- formed either in static or dynamic mode (Soxhlet apparatus) at $353 \mathrm{~K}$ with various surface/volume $(S / V)$ ratios. X-ray diffraction patterns were collected on a Siemens D5000 diffractometer using monochromatized $\mathrm{Cu} \mathrm{K} \alpha_{1}$ radiation $(\lambda=1.5406 \AA)$. SEM observations have been done on a Jeol $6700 \mathrm{~F}$ apparatus.

\section{Results and discussion}

\subsection{Chemical analysis}

In order to evaluate the reproducibility of the composition of perlite, chemical analyses have been performed on the five samples received from the Sardinia quarry by Thermal Ceramics at 4 months intervals. As shown in Table 1, the chemical composition is quite consistent, the largest variation concerns $\mathrm{Al}_{2} \mathrm{O}_{3}$. Besides the other elements usually found in perlite, $\mathrm{Al}$, $\mathrm{Na}, \mathrm{K}$ and $\mathrm{Ca}$, we also note the presence of a significant amount of iron. The whole content differs from $100 \%$ and it has been related to the presence of water and other minor elements.

The caesium content of samples heat treated at different temperatures between 873 and $1823 \mathrm{~K}$ indicates no Cs loss upon melting for all loading between 5 and $50 \mathrm{Cs}_{2} \mathrm{O}$ wt.\%. This means that Cs is perfectly trapped in the matrix.

\subsection{Thermal analysis}

A typical TG-DTA trace is shown in Fig. 1 for a 27.7 wt.\% $\mathrm{CsNO}_{3}$ (20wt.\% $\mathrm{Cs}_{2} \mathrm{O}$ ) sample. At low temperature, a first weight loss, around 2-3 wt.\%, has been attributed to adsorbed water. The main weight loss takes place between 713 and $913 \mathrm{~K}$ and corresponds to the nitrate decomposition. Surprisingly, an increase of the decomposition temperature is observed with increasing initial $\mathrm{CsNO}_{3}$ content. Moreover, the weight loss deviates from the value expected from the decomposition of $\mathrm{CsNO}_{3}$ into $\mathrm{Cs}_{2} \mathrm{O}$. The observed value fits with the formation of a mixture of $\mathrm{Cs}_{2} \mathrm{O}_{3}$ and $\mathrm{Cs}_{2} \mathrm{O}_{4}$. At low $\mathrm{CsNO}_{3}$ contents, the weight loss corresponds to the formation of $\mathrm{Cs}_{2} \mathrm{O}_{4}$ whereas the value expected for the formation of $\mathrm{Cs}_{2} \mathrm{O}$ is observed for the $50 \mathrm{wt} . \% \mathrm{Cs}_{2} \mathrm{O}$ sample. These results are perfectly reproducible. The fact that the nitrate is dispersed inside the pores may be a reason for the unexpected thermal behaviour.

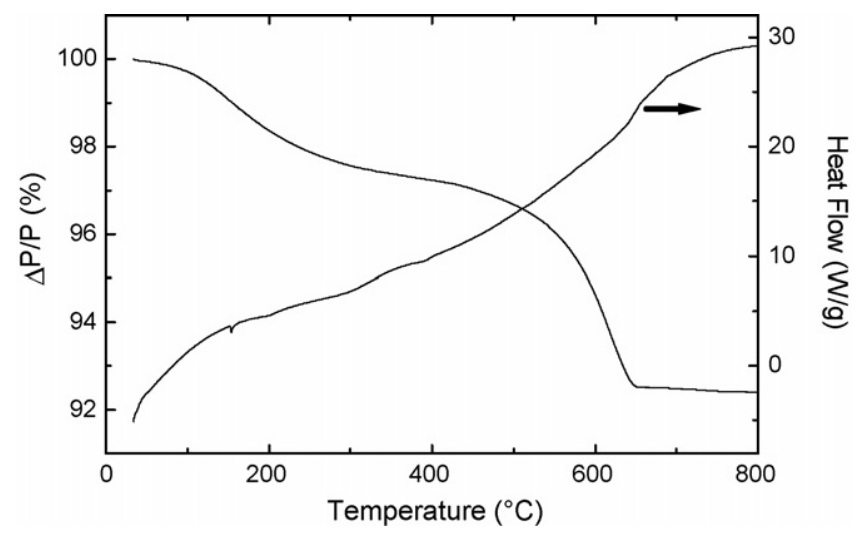

Fig. 1. TG-DTA traces of a $20 \mathrm{wt} . \% \mathrm{Cs}_{2} \mathrm{O}$ sample. 


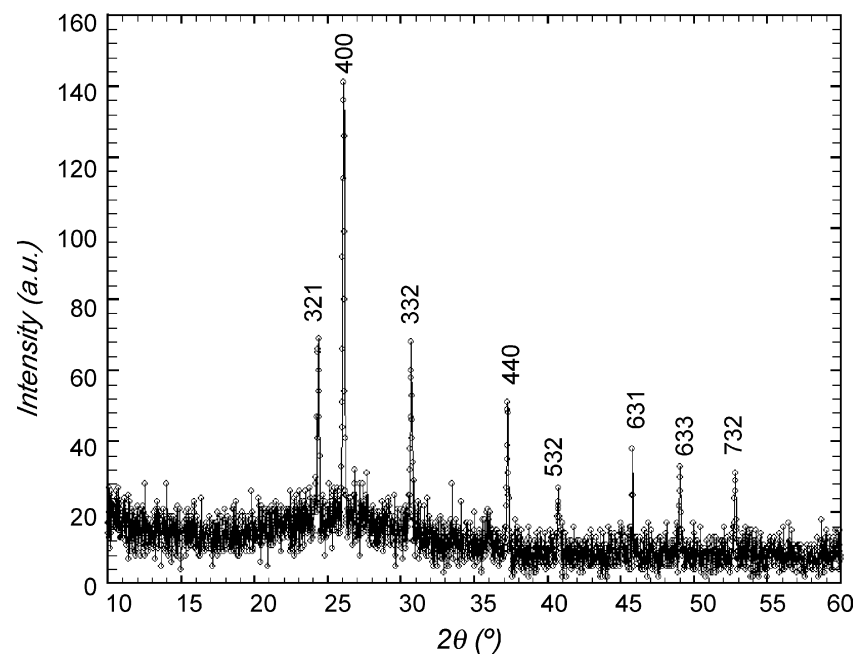

Fig. 2. X-ray diffraction pattern of $50 \mathrm{wt} . \%$ sample calcined at $700{ }^{\circ} \mathrm{C}$.

\subsection{X-ray diffraction}

X-ray diffraction patterns, recorded on powders annealed at different temperatures and containing different amounts of Cs, reveal the crystallization of pollucite, $\mathrm{CsAlSi}_{2} \mathrm{O}_{6}$ (Fig. 2). The pattern is usually characterised by a high background and a broad hump around $2 \theta=25^{\circ}$; the first is related to the presence of an amorphous phase and the second from poorly crystallised silicate. The resulting diffraction pattern has been compared with the corresponding JCPDS file No. 88-0055. No significant shift of the lines appears. This means that the other alkali cations in the original perlite have not been inserted (or at very minor levels) in the pollucite network. The presence of pollucite is evidenced by sharp peaks. Moreover, the presence of pollucite also depends on the Cs content and on the annealing time and temperature. To promote crystallization of pollucite, longer annealing times are needed with decreasing Cs content. For example, at $1373 \mathrm{~K}, 2$ and $12 \mathrm{~h}$ are needed for 50 and $25 \mathrm{wt} . \% \mathrm{Cs}_{2} \mathrm{O}$, respectively. Furthermore, the effect of grinding perlite yields a decrease of the crystallization temperature; for example for the $50 \mathrm{wt} . \%$ sample it is reduced to $973 \mathrm{~K}$ and requires only $2 \mathrm{~h}$.

\subsection{Sintering}

The sintering temperature of $1293 \mathrm{~K}$ has been chosen as it yields a good densification without deformation of the sample. For these experiments the powder was annealed at $1373 \mathrm{~K}$ and reground before to be shaped by pressing in $25 \mathrm{~mm} \times 3 \mathrm{~mm}$ round pellets. At higher temperatures, the viscous flow promotes the deformation. After annealing, the colour of the samples turn from a dirty white to brown, in relation with the oxidation of the small amount of $\mathrm{Fe}^{2+}$ to $\mathrm{Fe}^{3+}$. In view of a possible application, and in order to explore ways of shaping and sintering samples loaded with radionuclide solution, we have considered the possibility of a one-step sintering process, particularly avoiding the pre-heating steps. As described in Section 2 the grinded expanded perlite is loaded with caesium solution in an inconel crucible and a very low load is applied over the powder. Drying,

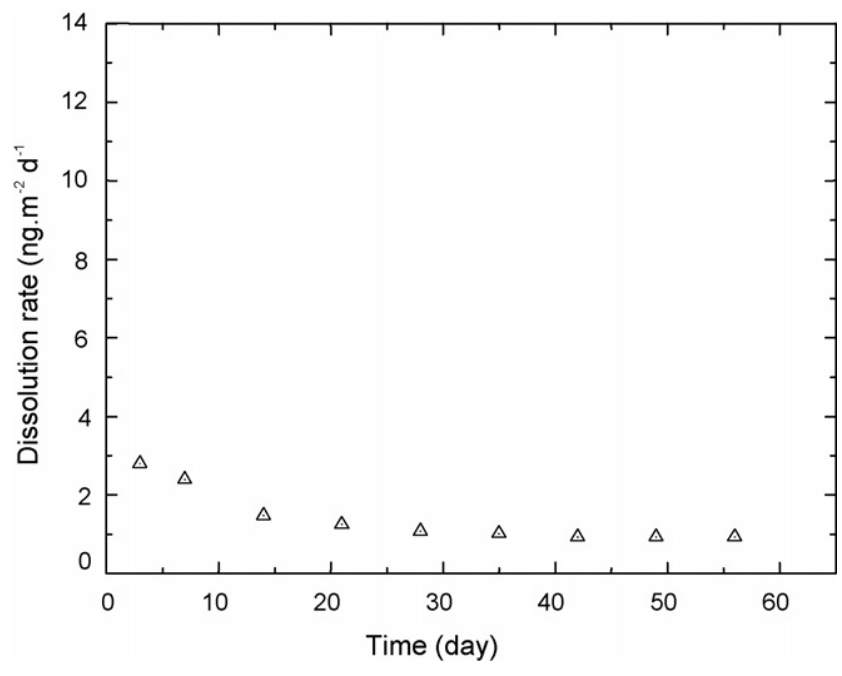

Fig. 3. Powder leaching results on perlite charged by $10 \mathrm{wt} \%$ in $\mathrm{Cs}_{2} \mathrm{O}$.

decomposition of nitrate and sintering take place successfully in the same heat treatment at $1293 \mathrm{~K}$. However, the for $50 \mathrm{wt} . \%$ caesium load the crystallization of pollucite at low temperature (973 K) inhibits full densification. Another way to promote full densification but at low temperature and therefore reduce the size of pollucite crystal was the flash sintering technique. It leads to a full sintered sample at $1073 \mathrm{~K}$. The densification of both samples, as received and grounded powder, exhibit densities better than $96 \%$ of the flash values.

\subsection{Leaching experiments}

Preliminary experiments performed on powdered samples yield a removal rate of $\mathrm{Cs}$ around a few micro grams per $\mathrm{m}^{-2}$ day $^{-1}$ at room temperature. Therefore, other experiments either on powdered or sintered pellets have been performed. The influence of the $S / V$ ratio has been tested on a powder, $10 \mathrm{wt} . \%$ $\mathrm{Cs}_{2} \mathrm{O}$ annealed at $1293 \mathrm{~K}$ for $1 \mathrm{~h}$, with a specific surface area around $1 \mathrm{~m}^{2} \mathrm{~g}^{-1}$, under static mode at $353 \mathrm{~K}$. Different quantities of powders were inserted in a closed container with a constant volume of $80 \mathrm{ml}$ water in order to achieve $S / V$ ratios of $12.5,125$ and $250 \mathrm{~cm}^{-1}$. Ten milliliters of aliquots were then taken at regular intervals and replaced by the same volume of deionized water. As shown in Fig. 3, the removal rate of Cs is always very slow with values of 2 to $7 \times 10^{-9} \mathrm{~g} \mathrm{~m}^{-2}$ day $^{-1}$ after 21 days or more. Moreover, the shape evolution with time is comparable to what is expected for a mechanism involving the formation of a surface gel. The values for the highest $S / V$ ratio are significantly lower and are in agreement with an improved efficiency of the surface gel. A sintered pellet with $10 \mathrm{wt} . \% \mathrm{Cs}_{2} \mathrm{O}$ has been cut in pieces and submitted to the same treatment at $353 \mathrm{~K}$. One piece has been taken at regular intervals for SEM. Observations at regular intervals up to 64 days contact with water (Fig. 4) show the presence of white spots at the surface, whose size and shape are independent of time. EDX analysis of the Cs content at the surface of the samples reveals a constant value close to the expected $10 \%$. No apparent degradation of the glass matrix is observed. 


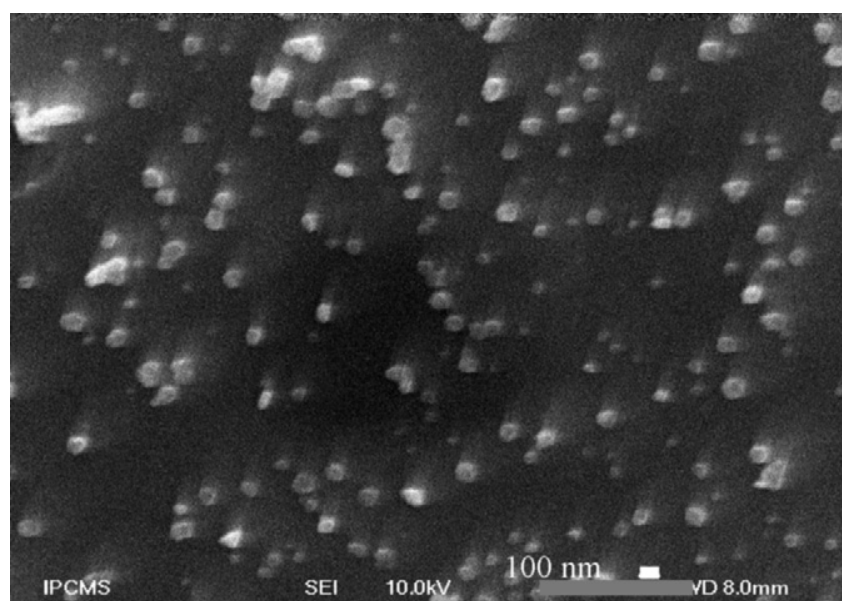

Fig. 4. SEM observation on leached sintered sample after 64 days.

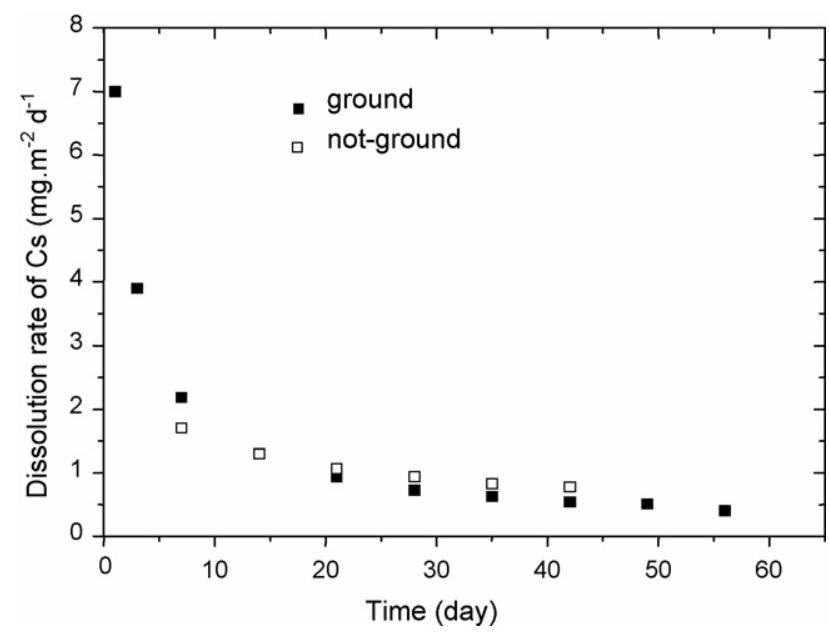

Fig. 5. Dynamic leaching test results on sintered samples.

Leaching experiments have also been performed on pellets either in static or dynamic mode. In static mode, for a pellet with 12 wt. $\% \mathrm{Cs}_{2} \mathrm{O}, \mathrm{S} / V=0.025 \mathrm{~cm}^{-1}$ (only the geometric surface of the samples has been considered for working out the rate) at $353 \mathrm{~K}$ the removal rate of Cs rapidly decreases and reaches a constant value after 40 days. The estimated removal rate is $1.5 \mathrm{mg} \mathrm{m}^{-2}$ day $^{-1}$ on the 7 th day and $0.6 \mathrm{mg} \mathrm{m}^{-2}$ day $^{-1}$ after 42 days. In dynamic mode, perlite pellets from both sintering processes (virgin or ground) were used and the experiments were performed with $450 \mathrm{ml}$ ion-exchanged water with the sample surfaces being around $7 \mathrm{~cm}^{2}$. Both samples give very similar results as shown in Fig. 5. Both processes resulted in very slow removal rates for $\mathrm{Cs}$, with a time evolution in agreement with the surface gel model. The $\mathrm{pH}$ monitored on a daily basis reveals no changes from a value close to 6 for both samples and for the two processes.

\section{Conclusions}

The results give great promises for the use of perlite as a potential matrix for confining natural caesium. We, therefore, propose it as a possible candidate for radioactive waste matrix. Its high stability, low removal rate of caesium in water due to two facts: high stability of the glass matrix against water corrosion, crystallisation of pollucite as the most stable crystalline form of caesium compounds. Moreover, its abundance, lost cost, the nontoxicity of the mineral makes it ideal for the environment and in favourable position as confinement matrix. The irreversible transformation to pollucite at high temperature and high densification achieved by sintering technique are additional bonuses. Current work in our group has extended the range of elements ( $\mathrm{Rb}, \mathrm{Sr}, \mathrm{Ba}, \mathrm{Ni}, \mathrm{Cd}, \mathrm{Nd}$ and $\mathrm{Eu}$ and I) that can be confined in perlite. Nevertheless, the effect irradiation by confining radioactive cation has to be studied.

\section{Acknowledgements}

The authors thank the GDR NOMADE (CEA, CNRS, EDF, COGEMA) for its financial support.

\section{References}

1. Hanchell, J. L., White, J. C., Thompson, M. R. and Hess, A. C., J. Phys. Chem., 1994, 98, 4463.

2. Konakolov, E. E., Starkov, O. V., Glagovskii, E. M., Myshkovskii, M. P., Kuprin, A. V., Pelevin, L. P. et al., Radiochemistry, 2002, 44, 420-422; Borovinskaya, I. P., Barinova, T. V., Ratnikov, V. I. and Ignatieva, T. I., In Advanced Technologies based on Self-Propagating and Mechanochemical Reactions for Environmental Environment, ed. G. Cao, F. Delogu and R. Orru. Research Signpost, Trivandrum, 2003, pp. 17-27.

3. Shin, J. M., Park, J. J., Kim, J. H., Yang, M. S. and Chun, K. S., In Proceedings of the International Conference on Future Nuclear Systems, 1999, pp. 756-761.

4. MacLaren, I., Cirre, J. and Ponton, C. B., J. Am. Ceram. Soc., 1999, 82, 3242-3244.

5. Miyagawa, N., Shinohara, N. and Okumiya, M., J. Ceram. Soc. Jpn., 1999, 107, 762-765.

6. Fryda, H., Vetter, G., Ollitrault-Fichet, R., Boch, P. and Capmas, A., Adv. Cement Res., 1996, 8, 29-39;

Mimura, H., Akiba, K., Ishiyama, S. and Eto, M., J. Nucl. Sci. Tech., 1996, 33, 511-518;

V.I. Bogdanova, B.A. Fursenko, G.I. Galai, I.A. Belitsky, L.M. Predeina, V.S. Pavlyuchenko, I.V. Drobot, NATO ASI Series, Series 1: Disarmament Technologies, 1998. pp. 69-84;

Bosch, P., Caputo, D., Liguori, B. and Colella, C., J. Nucl. Mater., 2004, 324, 183-188.

7. Alloy, A. S., Iskhakova, O. A., Kol'tsova, T. I. and Trofimenko, A. V., In Proceedings of International Congress on Glass, 1998, pp. 907-913; Lashchenova, T. N. and Stefanovskii, S. V., Perspektivnye Materialy, 2000, 5, 95-105;

Inagaki, Y., Idemitsu, K., Arima, T., Maeda, T., Ogawa, H. and Itonaga, F., Mat. Res. Soc. Symp. Proc., 2002, 713, 589-596;

Lambregts, M. J. and Frank, S. M., Microporous Mesoporous Mater., 2003 , 64, 1-9.

8. Ogorodova, L. P., Melchakova, L. V., Kiseleva, I. A. and Belitsky, I. A., Thermochim. Acta, 2003, 403, 251-256.

9. Yanase, I., Tamai, S. and Kobayashi, H., J. Ceram. Soc. Jpn., 2003, 111, 533-536.

10. Hess, N. J., Espinosa, F. J., Conradson, S. D. and Weber, W. J., J. Nucl. Mater, 2000, 281, 22-33.

11. Fortner, J., Aase, S. and Reed, D., Mat. Res. Soc. Symp. Proc., 2002, 713 , 527-533.

12. Bolen, W. P., Am. Ceram. Soc. Bull, 1998, 77, 111-112.

13. S. Vilminot, C. Estournès, J.L. Rehspringer, French Patent, No. 02 11689, 2002. 